\title{
Body image concerns screening tools: creation and validation of Polish language versions of Body Shape Questionnaire-34 (BSQ-34) and Functionality Appreciation Scale (FAS)
}

Ida Yurtsever

Dermatology and Aesthetic Medicine, Wroclaw, Poland https://orcid.org/0000-0002-3395-2820 Łukasz Matusiak

Wroclaw Medical University: Uniwersytet Medyczny im Piastow Slaskich we Wroclawiu

Marta Szepietowska

Wroclaw Medical University: Uniwersytet Medyczny im Piastow Slaskich we Wroclawiu

Chris Evans

The University of Sheffield

Jacek Szepietowski ( $\nabla$ jacek.szepietowski@umed.wroc.pl )

The University of Sheffield https://orcid.org/0000-0003-0766-6342

\section{Research}

Keywords: BSQ-34, BIQLI, FAS, BAS-2, creativity, bodily senses

Posted Date: June 28th, 2021

DOI: https://doi.org/10.21203/rs.3.rs-623500/v1

License: (c) (i) This work is licensed under a Creative Commons Attribution 4.0 International License.

Read Full License 


\section{Abstract}

Background: Body image can be defined as individual perception of own body and related behaviors. Body dissatisfaction may lead to low self-esteem, depression and anxiety. Body image can be evaluated and quantified. Among various number of instruments assessing body image, there are: Body Shape Questionnaire-34 (BSQ-34) and Functionality Appreciation Scale (FAS).

The aim of this study was to translate and validate the Polish version of both: BSQ-34 and FAS.

Methods: Both, forward and backward translations of the original English versions of BSQ-34 and FAS questionnaires was performed in accordance with international standards. The validation of BSQ-34 was conducted on 89 and FAS on 103 individuals. They completed the questionnaires twice with 3-6 days interval. The subjects also filled the Polish versions of BIQLI (Body Image Quality of Life Inventory) and BAS-2 (Body Appreciation Scale-2) for convergent validity procedure.

Results: The Polish version of both BSQ-34 and FAS demonstrated very good and good internal consistency and reproducibility. Convergent validity indicated a moderate relationship between BSQ-34 and BIQLI, and strong correlation between FAS and BAS-2.

Conclusions: To conclude the Polish version of both BSQ-34 and FAS questionnaire showed sufficient internal consistency and reliability. They can be used in clinical practice in subjects speaking Polish language.

Trial registration: Wroclaw Medical University EC approval no: 2/06/20

\section{Full Text}

This preprint is available for download as a PDF. 